\title{
Analysis of Physical Education Teaching Mode Based on Computer Multimedia and Network System
}

\author{
Yang $\mathrm{Ju}^{*}$ and Haibo Wan \\ Department of Physical Education, Tianjin University of Commerce, China \\ Corresponding author: Yang Ju, juyang1977@sina.com
}

\begin{abstract}
At present, the development and application of computer and network technology has penetrated into all fields of society, especially in the field of physical education. In this paper, the authors analyze physical education teaching mode based on computer multimedia and network. In the network environment, physical education has an advantage in the educational function and resources, and provides learners with a modern teaching environment. Through a questionnaire survey, $74.2 \%$ of the students said that the effect of multimedia teaching was significantly higher than the traditional physical education, $63.1 \%$ of students agree that computer assisted instruction can stimulate interest in learning. At the same time, we find out the problems existing in the teaching of physical education, and provide some suggestions.
\end{abstract}

Keywords: Computer multimedia, Network technology, Physical education, Teaching mode

\section{Introduction}

At present, the development and application of modern science and technology, which is the core of computer and network technology, has penetrated into all fields of society, especially in the field of education [1]. With the continuous improvement of the application of the network technology, the concept of education information is gradually being put forward with the appearance of the information technology Expressway in 1990s. How to meet the challenge of modern science and technology, especially information technology, how to apply the computer network technology in time, improve the quality of teaching and cultivate high quality workers, has aroused widespread concern in the education field [2]. Network education is a new type of educational model, which refers to the students in the guidance and cooperation of teachers, the use of computer network technology to obtain learning guidance and information resources, and the effective way to achieve learning goals [3]. It can be summarized as follows: in the network environment, the modern education thought and learning theory as a guide, give full play to the education function of the Internet and education resources, provide a teaching and learning environment to educators and learners, the transfer of digital education information, to carry out synchronous or asynchronous interactive teaching activities. Mainly includes the following aspects: electronic learning, distance learning, network teaching system, online education, etc.

Network education is a new teaching mode which appears with the development of computer network technology. The domestic sports industry has been devoted to the research on the integration of the network education technology and the university physical education. In this paper, the use of field research, questionnaire survey, comparative description of the application of network technologies in PE education in the analysis and other research methods, analysis of application pattern of network education technology in the teaching of college sports teaching, advantages and problems [4]. Making judgments on the role of network teaching in the teaching of Public Physical 
Education in Colleges and universities [5]. The status quo of college sports website construction in China shows a number of low, poor quality, lack of development of education function; application of network technology in education in PE Teaching in Colleges and universities is mainly relying on the establishment of the sports curriculum material library of campus network, the network teaching as a supplement of classroom teaching and development, undertake the task of teaching knowledge through sports; comparative analysis and application of network education technology to broaden the traditional classroom teaching, to cultivate students' learning ability, has the positive significance of lifelong learning habits, physical fitness, skills of goal realization have limitations; the successful application of network technologies in PE educational management, assessment of student selection, performance management has. Great effect; evaluation of university teaching mode, the teaching mode displays some superiority.

\section{Multimedia Technology and Network Sports Teaching}

\subsection{Multimedia Technology}

The information society is social media, people's study, life and work cannot do without a variety of media, so the spread of education information is no longer a single character of information dissemination, an important part of modern educational technology has become a modern teaching, it can play a positive role in changing the teaching methods and optimizing teaching design and improving the quality of teaching [6-7]. The modern multimedia teaching methods can effectively compensate for the shortcomings of traditional teaching, multimedia technology integrates all information media, such as video, computer, projector, tape recorder, multi-function display instrument, in the teaching process through choreographed videos, animation, threedimensional sense for students to provide a wide range of information fully mobilize students' visual, auditory, tactile and other sensory comprehensive and coordinating role, to enable students to achieve rich perceptual knowledge from the perspective of intuitive vivid, eventually forming law and the law of psychology. Therefore, the multimedia technology has the incomparable advantage of the traditional teaching method, and it is the inevitable choice of the modern classroom teaching to deal with the times demand.

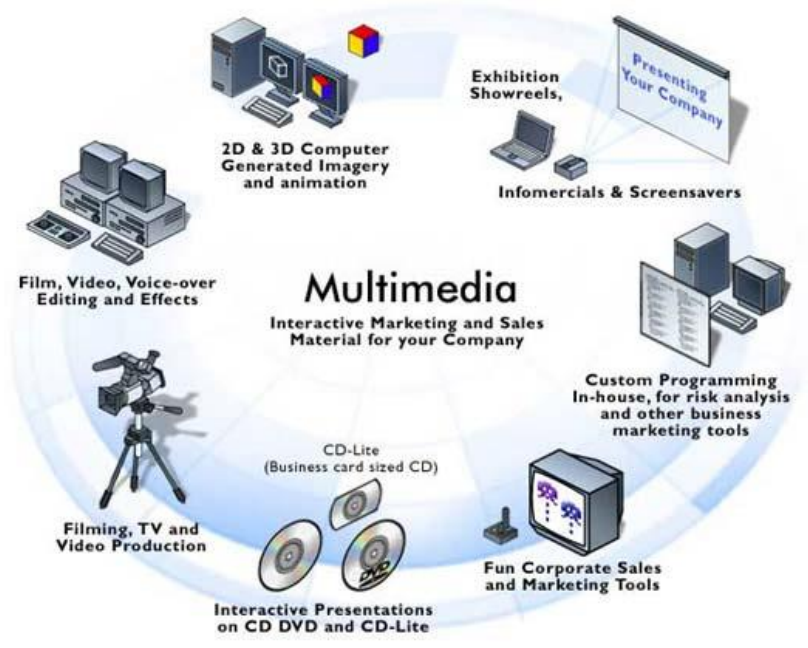

Figure 1. Multimedia Devices

The application of modern information technology in teaching activities is an important means to improve the quality of teaching. Therefore, the hardware construction of the 
multimedia teaching system is actively involved in the development of the information technology [8]. It is an urgent task for the school to speed up the reform and development. Modern educational technology including audio-visual technology and information processing technology in two categories, the multimedia teaching system is the unity of the effective combination, should be the construction of digital teaching environment through the campus network, electronic library, multimedia classrooms and improvement, provide the necessary material guarantee for the modernization of teaching by using multimedia technology to optimize teaching design. First, the use of multimedia technology can expand the knowledge of classroom teaching, the language and picture information are complementary, and the writing time is saved, the author found that the use of multimedia technology can increase in unit time [9]. The above information and multimedia technology is presented to students is dynamic information, sound effects and different image transform can provide diversified and stereoscopic information, constantly stimulate the nerve center of learners, conducive to learning and memory of their activities. Second, multimedia technology can enrich the form of classroom teaching, deepen the reform of classroom teaching methods. The basic performance of the traditional discussion teaching is the question and answer between the speech, the information channel is single. In a word, through the multimedia teaching method can conveniently and quickly spread the advanced information, but also can stimulate students' thinking, intellectual development, cultivate the students' ability to analyze and solve problems, the multimedia technology to create a favorable learning environment for students.

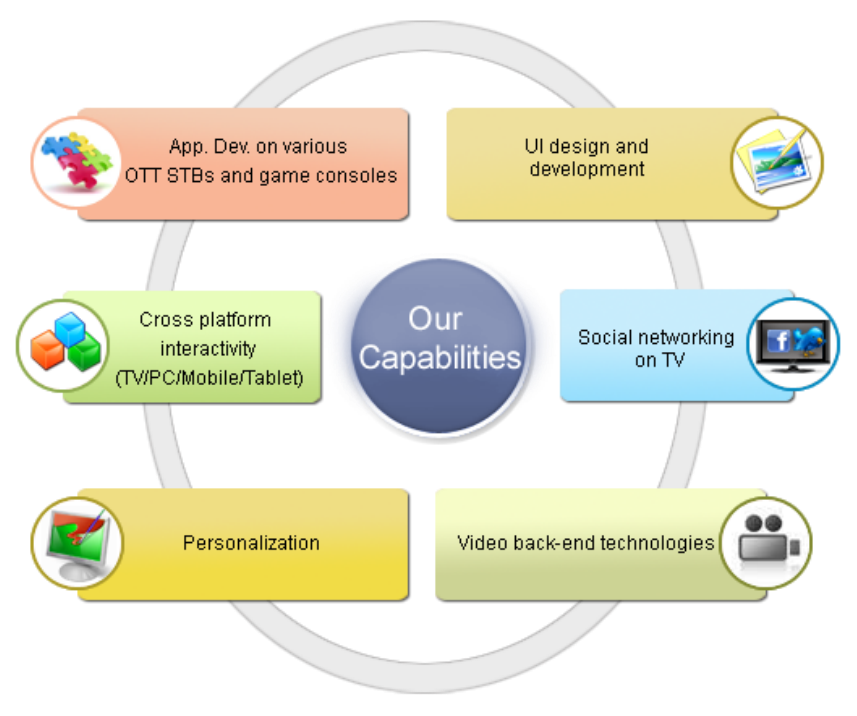

Figure 2. Multimedia Technology Application

The basic purpose of multimedia teaching is to promote students' comprehensive development in the process of learning. The teacher through the means of computer, network, slide, multimedia technology, communication can be more effective information in the unit time, bring new vigor and vitality to the field of education and teaching. But the traditional view that the more a means of multimedia aided teaching is, in the face of the arrival of the information society, we should re-examine the value of multimedia teaching, the height of the ascension to the modern education idea. The remarkable characteristic of the information society is that knowledge and information are growing exponentially, but any knowledge and information is a public resource, which is open and shared. The advantages of multimedia teaching lies in the knowledge and information filtering and integration is convenient and fast, therefore, teachers should go through the process of multimedia teaching, show a lot of information to the students, the objective 
perspective, a reasonable choice of means, such as the method, scientific use, correct attitude towards the network, through the network learning skills, in order to guide them to develop autonomous learning awareness and habits, improve their learning ability. \%, century talent is how to learn the talent, founded on the technology of modern multimedia classroom will create a more broad world for the all-round development of students, will lay the foundation for their lifelong learning.

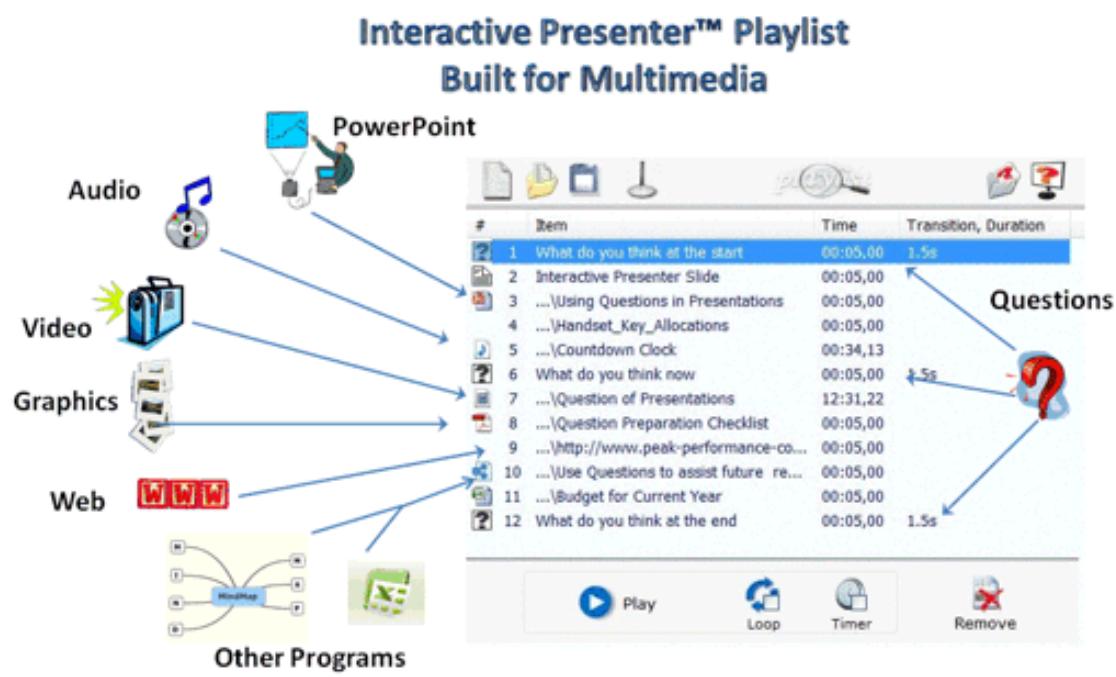

Figure 3. Multimedia Classroom

\subsection{Network Education}

Network education technology because of its own characteristics, it is inevitable in the process of education information technology plays an increasingly important role in the process of education. From the point of view of education, network education technology has the characteristics of multimedia teaching materials, globalization of resources, individualized teaching, autonomous learning, task cooperation, management automation and so on. These features also undoubtedly conform to the new concept of quality education. Multimedia materials can help the students to improve the students' interest, there are difficulties to learn technology, the successful application of multimedia teaching has been proved out; individual teaching, learning autonomy is conducive to the development of students' personality and creativity; task cooperation refers to students through the way of cooperation to complete learning tasks, this is the current direction of development of international education; management automation refers to the use of computer teaching management, including test score and computerized diagnosis of learning problems, the use of electronic documents to support the reform of teaching evaluation, implementation of assessment for learning. These characteristics are of great practical significance to improve the quality of teaching, and to optimize the educational administration management of school physical education.

In terms of the basic theory of network education, the characteristics of network education technology is very suitable for students to learn sports. The characteristics of sports information resources under the network environment determine that the network teaching has certain advantages in physical education. 


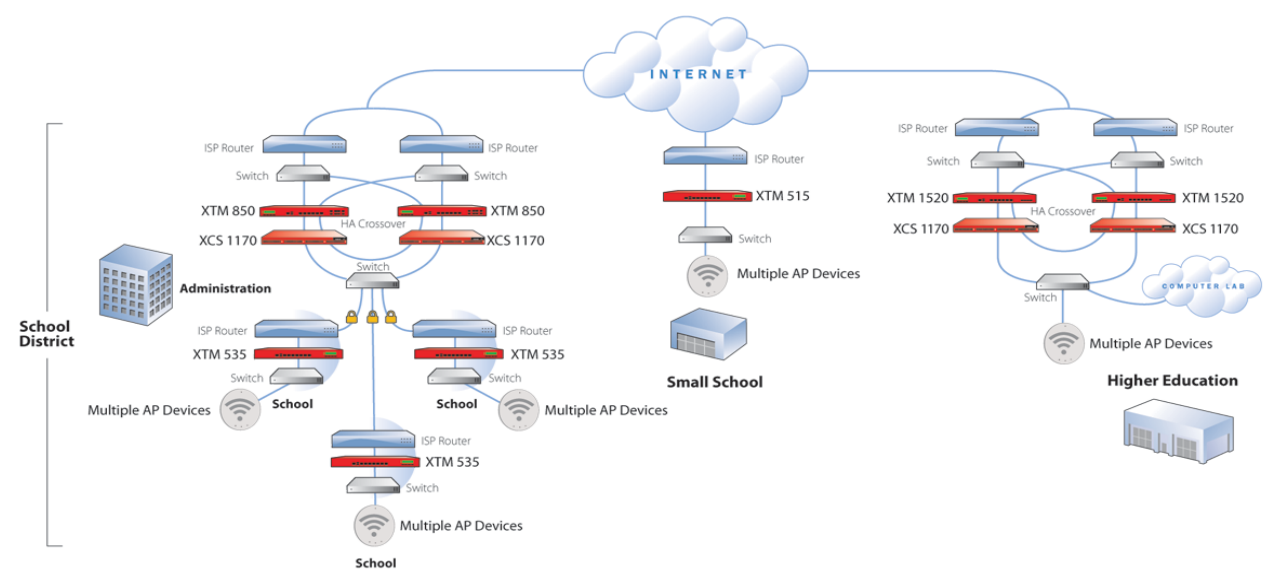

Figure 4. Network Education System

- Massive information resources: Online sports news, sports events, such as instant messaging, but also has all kinds of scientific research literature data, historical data, sports performance, personal information, such as database information. There are a lot of sports technology teaching material, there are a lot of health care knowledge, as well as many international and domestic sports organizations, the rich information resources are not comparable to the traditional teaching media.

- Species diversity: In addition to text information, also includes a large number of non text information, such as images, audio, video, software, database and other forms coexist, showing a multi type, multimedia, non standardized, cross regional, cross language features etc.. The key for some sports course, difficulty of teaching have a face-to-face education that can not be achieved.

- Decentralized distribution: Network information is distributed and distributed, open, disordered, but because of the unique way of hypertext links, a powerful search function, so that there is a strong correlation between the content of the degree.

- Sharing: In addition to the general sense of cyber source sharing, a web page it can be used for all Internet users to access information, do not exist in the traditional media because of restrictions on the number of copies of the information generated can not obtain the phenomenon.

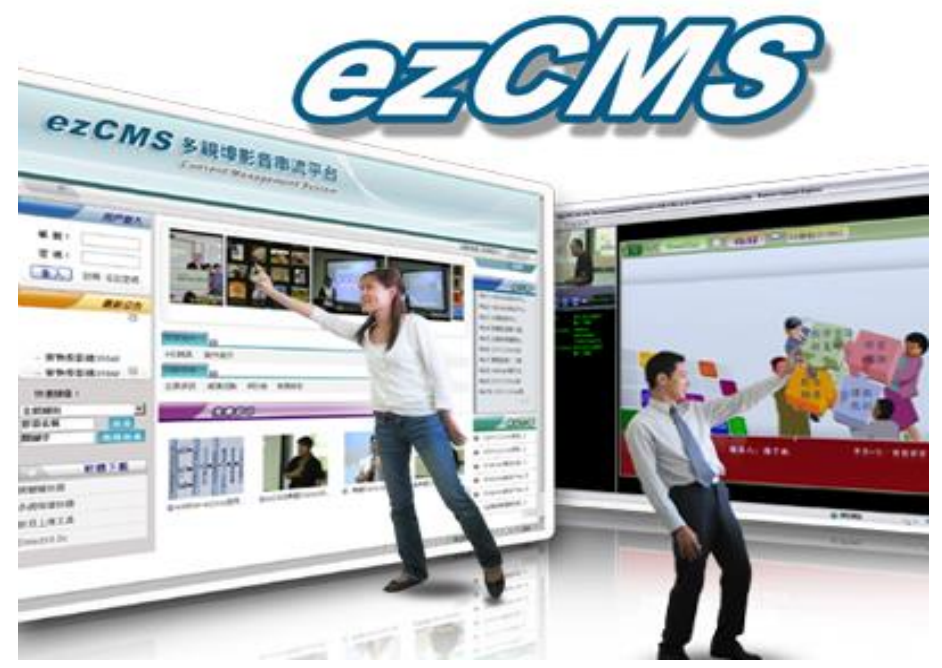

Figure 5. Online Course Education 


\section{Current Situation and Problems of the Application of Media Physical Education}

\subsection{Problems in Multimedia Physical Education Teaching}

(1) understanding of multimedia teaching is not in place

In multimedia teaching, "teaching" is always the main body, which is in line with the "multimedia" teaching, teaching and promote teaching, excessive application of multimedia technology will dilute the teaching goal, resulting in unnecessary burden for teachers and students, teaching efficiency is low. Compared with traditional teaching, multimedia teaching essence is the change of information transfer, presents the means and methods, is no longer confined to the past chalk, blackboard, the teacher himself, but to make full use of modern multimedia technology, the most suitable organizational learning method of the students teaching content, teaching information, teaching situation, teaching design in order to achieve the purpose of effective teaching. The so-called effective teaching refers to the teacher after a period of teaching, so that students get a specific progress or development, that is to say, the students have no progress or development is the only indicator of teaching effectiveness. Teachers use multimedia teaching, is to better achieve effective teaching.

(2) Sharing curriculum resources is a serious shortage

In the research of multimedia teaching in Colleges and universities, it is a serious problem, that is, the quality of multimedia courseware made by teachers is not high, and teachers also think that making courseware is too much energy. On the one hand, it is related to the ability of teachers' information technology, on the other hand, it is too little to be shared by teachers. Although the modern information society development, especially the large amount of information on the Internet, but related to each teacher's classroom teaching resources, there are many differences in geography, culture, teaching objects, teaching contents, which requires teachers based on possession of certain curriculum resources, make the necessary changes according to the needs of.

(3) Teacher's information technology ability is not high

Teachers' ability of information technology is not high, mainly in the technical ability of teachers to make courseware. Most teachers adopt Powerpoint PPT courseware, but also quite a few teachers only copy and paste the text, images, video, interception of file format conversion, insert hyperlinks and computer technology are not familiar with, multimedia courseware has become a simple electronic textbooks. Teacher's information technology ability is not high also displays in the teacher in the process of using the multimedia courseware, can not skillfully, the scientific use of multimedia equipment. 


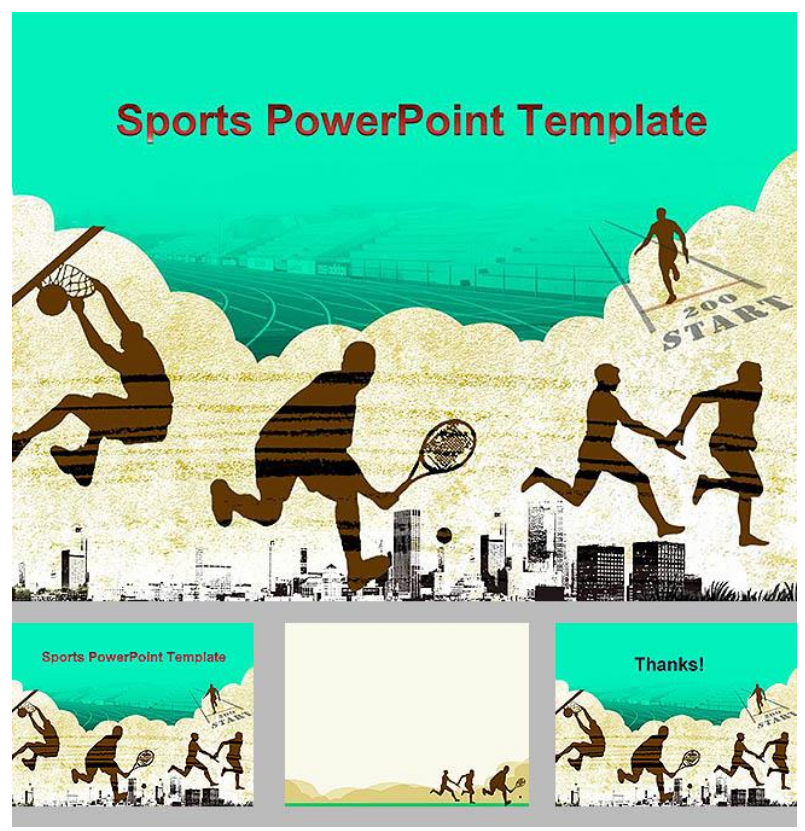

Figure 6. Sports Teaching PPT

(4)Multimedia teaching mode is single

Multimedia teaching mode mainly includes multimedia projection teaching, multimedia interactive teaching, individualized teaching and remote network teaching. Multimedia projection teaching is a kind of multimedia classroom teaching mode which is used by most of the teachers in Colleges and universities. Multimedia interactive teaching and individualized teaching mode is an important supplement to the classroom teaching, the former is mainly through the network, teachers and learning

\subsection{Suggestions on Optimizing the Teaching of Multimedia Physical Education}

(1)Strengthening the cultivation of teachers' Multimedia Teaching

The traditional pre service teacher education curriculum in our country is only three courses of pedagogy, psychology and teaching method, and does not include the course of educational technology. Under the current new teacher education system, some teachers training institutions have set up a complete set of teacher education curriculum. Recommendations from two aspects of theory and practice teaching, it should include the necessary information technology applications and instructional design theory of content, such as web production, Powerpoint. Teaching design theory, combined with the knowledge of students' education and learning psychology, introduces different teaching design concepts through case analysis.

(2)Establish curriculum resource database

The establishment of curriculum resource database, schools should provide a certain financial support and system support. By staff of teachers and educational technology professional participation, full communication and exchanges, to the college or department for organizational units, with similar courses for the construction unit, to establish a curriculum resource base, and sharing for teachers. Breaking the whole discipline knowledge system in a single way, in the form of special topics, the establishment of the corresponding resource library. In addition, it should make full use of the excellent curriculum resources of the school, to strengthen publicity and resource sharing. Colleges and universities have established different levels of quality courses, the same or similar subjects between the excellent course should be fully shared resources. 


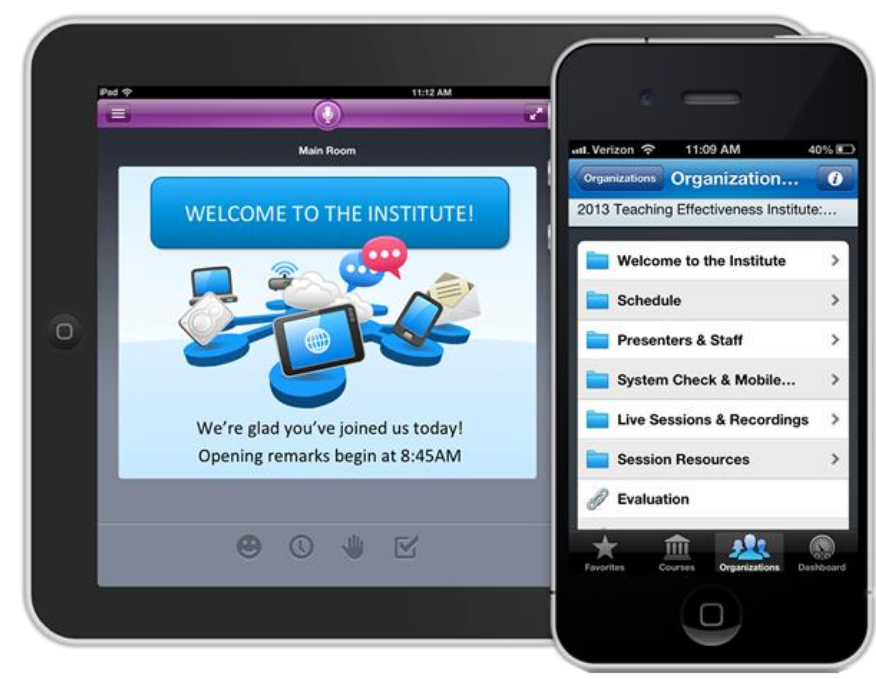

Figure 7. The Online Course Database

(3)Strengthen the practice of multi media teaching mode

The positive role of multimedia teaching is not only reflected in the classroom teaching, students' learning is not confined to the classroom, multimedia teaching in Colleges and universities should be a model for coexistence, to assist teachers in classroom teaching, after-school tutoring students self-study, improve the teaching quality of teachers in Colleges and universities. Multimedia teaching has obvious advantage in the teaching situation, stimulate the enthusiasm and initiative of student learning, cultivating students' creative thinking ability, based on the learning outcomes of students, teachers' professional ability of multimedia teaching from teaching, technical, artistic and other aspects, the objective evaluation of the multimedia teaching the target, process, method, technique and effect etc..

\section{(4)Strengthening multimedia teaching evaluation}

Multimedia teaching is a combination of multimedia technology and modern education theory, communication theory, its teaching aim is to better carry out the teaching purpose, teaching plan, promote the optimization of teaching effectiveness, improve learning efficiency. Therefore, the application of multimedia technology is not only the reform of teaching methods, but also lies in the change of teaching ideas, teaching ideas and the choice of teaching content, the implementation of teaching design. At present, the teaching evaluation which adapt to the traditional teaching method has been quite perfect, which effectively promoted the development of the traditional teaching method.

\section{The Influence of Multimedia Technology in Physical Education}

\subsection{The Function Evaluation of Physical Education Teaching}

Under the network environment of the sports teaching and the teaching of traditional sports than in the system to increase the students' autonomous learning this link. Autonomous learning in this way using cyber source, to broaden the traditional physical education function, also have a corresponding effect on the students. The research shows that the students under the network environment to cultivate students of course the sports learning ability, cultivate a lifelong sports consciousness, understand the more technical aspects of the project evaluation function is superior to the traditional teaching; to meet their interest in sports, no significant difference compared with the traditional teaching learning effect evaluation from one or two items of technology; and in the physical 
exercise, enhanced physique evaluation of utility is lower than that of the traditional sports teaching.

Table 1. Teaching Effect Evaluation

\begin{tabular}{|c|c|c|c|c|c|c|}
\hline group & $\begin{array}{c}\text { Sports } \\
\text { learning } \\
\text { ability }\end{array}$ & $\begin{array}{c}\text { Technical } \\
\text { skills }\end{array}$ & $\begin{array}{c}\text { Physical } \\
\text { exercise }\end{array}$ & $\begin{array}{c}\text { project } \\
\text { technology }\end{array}$ & $\begin{array}{c}\text { Cultivate the } \\
\text { consciousness }\end{array}$ & $\begin{array}{c}\text { Sports } \\
\text { interest }\end{array}$ \\
\hline multimedia & $\mathrm{M}=0.49$ & $\mathrm{M}=0.76$ & $\mathrm{M}=0.54$ & $\mathrm{M}=0.62$ & $\mathrm{M}=0.34$ & $\mathrm{M}=0.59$ \\
\hline $\begin{array}{c}\text { traditional } \\
\text { teaching }\end{array}$ & $\mathrm{M}=0.12$ & $\mathrm{M}=0.43$ & $\mathrm{M}=0.75$ & $\mathrm{M}=0.13$ & $\mathrm{M}=0.45$ & $\mathrm{M}=0.64$ \\
\hline $\mathrm{MSE}$ & 0.036 & 0.22 & 0.43 & 0.041 & 0.025 & 0.38 \\
\hline $\mathrm{T}$ & 7.245 & -2.013 & -3.552 & 8.132 & 3.564 & 1.024 \\
\hline $\mathrm{P}$ & $<0.01$ & $<0.01$ & $<0.01$ & $<0.01$ & $<0.01$ & $>0.05$ \\
\hline
\end{tabular}

Because the network teaching mode, teaching material resources and more massive and more optional learning different project technology, sports knowledge and information teaching environment the students get more timely and accurate, which will make the students contact sports information and knowledge understanding is much higher than that of pure traditional teaching teachers and taught. In the process of learning, students' autonomous learning initiative is much higher than that of the traditional teaching, which is more conducive to students to master the more you are interested in sports knowledge. By contrast the data of the two kinds of teaching environment can be seen that the training of network teaching model on students' physical learning ability effect is superior to the traditional teaching. $74.2 \%$ of students sports network teaching environment said the use of cyber source study of middle school physical education to the physical knowledge, far higher than the $16.1 \%$. network teaching of traditional sports teaching mode Model is based on the constructivism learning theory, emphasizes students as the center. This teaching model can provide illustrations for the learners, rich and colorful interactive interface, can provide to meet the human associative thinking and associative memory characteristics for learners, according to the structure of the large-scale knowledge base and information base, and easy to stimulate the interest of learners. The network teaching form truly make the learners actively construct knowledge and meaning, to achieve their ideal goal of knowledge acquisition to self renew and even create new knowledge. This has great effect on cultivating students' learning ability.

\subsection{The Influence of Multimedia Teaching on Students}

Students in the multimedia teaching mode for the sports information sources are ranked as cyber source television broadcasting; physical education; learning; newspapers and books; conversation. Students under the traditional teaching pattern for the sports information sources of the order for television broadcasting; degree in physical education learning; newspapers and books; cyber source; chat the conversation. Obviously, the application of network education technologies has changed the way of obtaining knowledge and knowledge of sports students abundant access. Students rely on the network media access to sports knowledge, more information than PE class teaching, network teaching has indicated that play the role of classroom teachers in knowledge acquisition and replacement, the amount beyond the traditional teachers in the teaching form. According to the survey, feel more interested than traditional teaching in physical education, the application of computer network technology assisted teaching has $63.1 \%$ students, $14 \%$ of the students said they were not interested, and $1.5 \%$ and $8.4 \%$ of the students said they did not know and feel no two. The application of network education technology will make a considerable part of the students' interest in physical education has increased. 
Table 2. Multimedia Learning Factors

\begin{tabular}{|c|c|c|c|}
\hline content & Number & ranking & Percentage \\
\hline Computer courseware & 234 & 1 & $61.2 \%$ \\
\hline Computer facilities & 116 & 2 & $30.1 \%$ \\
\hline Multimedia learning habits & 109 & 3 & $29.3 \%$ \\
\hline Lack of physical knowledge & 102 & 4 & $28.6 \%$ \\
\hline Multimedia learning skills & 84 & 5 & $24.1 \%$ \\
\hline Lack of interest in sports & 79 & 6 & $23.2 \%$ \\
\hline
\end{tabular}

The learning quality of the student network directly affects the physical network teaching development prospects. Reveal the influence factors of sports students learning, targeted improvement of network educational technology in sports teaching further application, has the decisive significance. Research shows that the main factors influencing the students' autonomous learning by using multimedia network material production level is low, the lack of network sports material and condition of the Internet, network learning is different from learning, self learning ability of several elements. Both objective factors and subjective factors, including a large number of them. The objective material limit there are subjective, capacity constraints. These are influencing students' learning by Internet visible factors. In addition, the learning motivation of students learning behavior of students will also have a certain impact. Motivation is to initiate and maintain the activity tendency or will is sent out from the individual internal energy or impulse to guide his individual behavior point to a specific target, and this behavior will be maintained for a period of time the internal state and the process. Students participate in sports learning motivation is obvious tendency of diversification, which improve the physical quality master, special sports knowledge, technology and skills, promote the comprehensive development of individual students is main motivation for learning elective course.

\section{Table 3. Investigation of Learning Motivation in Physical Education Class}

\begin{tabular}{|c|c|c|c|}
\hline content & number & ranking & Percentage \\
\hline Physical exercise & 342 & 1 & $74.2 \%$ \\
\hline Learning motor skills & 323 & 2 & $72.0 \%$ \\
\hline Improve personal ability & 293 & 3 & $69.5 \%$ \\
\hline recreation & 162 & 4 & $38.2 \%$ \\
\hline Academic record & 151 & 5 & $37.5 \%$ \\
\hline Sports habit & 143 & 6 & $36.4 \%$ \\
\hline
\end{tabular}

Due to the current school sports students learning motivation deviation, so they do not pay attention to the role of multimedia learning sports, sports studies to adopt an indifferent attitude. This kind of students in the class in the process of network learning, autonomous learning is easy to become a mere formality. Specific performance in: some students in order to get more than the usual results, they will often log on to the network learning system. There are some students mentioned that several factors: lack of learning time, affect the health, and practice. The objective factors, the school can improve infrastructure, improve the level of network material to achieve; and for the subjective factors, the school should cultivate students' sports values, learning method and so on. In the course of future sports network in how to solve these problems effectively, has become a key to future sports network teaching.

\subsection{The Attitude of Sports Multimedia Education}

The data shows that students' positive effects on the application of multimedia in sports teaching has a certain degree of identity. Most of the students on the teaching mode of 
neutral or indifferent attitude. $30 \%$ students think the network technology in physical education available, and $27.1 \%$ of students hold a more rational attitude, they that the application of network education technology in the teaching of physical education should be decided according to the concrete conditions of the teaching content. The survey showed that $59.38 \%$ of teachers think that network teaching can be popularized, $40.6 \%$ of the teachers think that network teaching can only be applied to individual.

\section{Table 4. Network Teaching Effect Evaluation}

\begin{tabular}{|c|c|c|}
\hline option & number & Proportion \\
\hline Very good effect & 250 & $61.3 \%$ \\
\hline Larger effect & 142 & $34.2 \%$ \\
\hline commonly & 190 & $41.0 \%$ \\
\hline Little effect & 65 & $13.5 \%$ \\
\hline Never tried & 37 & $7.2 \%$ \\
\hline
\end{tabular}

Visible, although the students of multimedia in Physical Education in most acknowledge, but both students and teachers accept the multimedia teaching of the new teaching means there exist certain differences. Influenced by the traditional concept of sports, some teachers and students think that physical exercise is the main task of physical education for the sports, teaching and cultivating students' cognitive ability, emotion, lack of understanding of the functions. But do not pay attention to sports teaching on students' knowledge of physical education and health care, scientific exercise methods to teach. This leads to doubt the practical significance of many students and teachers on the teaching mode of multimedia teaching. Teaching aided by cyber source, itself has a positive effect, but due to the specific problems in practice, the teaching quality has been greatly affected, the impact on the students in the teaching form of recognition in a great degree The same.

\section{Conclusions}

In the teaching experiment results show that the application of multimedia technology in the teaching of physical education has greatly changed the students' physical source of knowledge structure and learning ways of cultivating the students' learning ability, habits of lifelong learning has obvious role in promoting; network teaching form can make up for the traditional single teaching content, defect class too little; the network education technology of asynchronous nature of teaching and modern teaching means more optimized teaching mode has brought inspiration for the school sports exploration, is conducive to the deepening of teaching reform. The practice proved that network teaching as an extension of the school sports class, has a certain effect on the students' Sports auxiliary learning.

\section{Acknowledgments}

The work of this paper is supported by Tianjin education science in planning project Issue number (HE3017). 


\section{References}

[1] N. R. Mastroleo and R. Turrisi, "Examination of post-training supervision of peer counselors in a motivational enhancement intervention to reduce drinking in a sample of heavy-drinking college students", Journal of Substance Abuse Treatment, vol. 39, (2010), pp. 289-297.

[2] S. J. Hua and L. Hong, "Explore the Effective Use of Multimedia Technology in College Physics Teaching”, Energy Procedia, vol. 17, (2012), pp. 1897-1900.

[3] R. A. Sabella, "School counselors perceived importance of counseling technology competencies", Computers in Human Behavior, vol. 26, (2010), pp. 609-617.

[4] Z. Huang and M. Benyoucef, "From e-commerce to social commerce: A close look at design features", Electronic Commerce Research and Applications, vol. 12, no. 4, (2013), pp. 246-259.

[5] C. Zhang and X. Chen, "Use of Multimedia in Gross Infective Pathogen Experimental Teaching", Procedia Engineering, vol. 37, (2012), pp. 64-67.

[6] C. Krstev, and A. Trtovac, "Teaching Multimedia Documents to LIS Students", The Journal of Academic Librarianship, vol. 40, no. 2, (2014), pp. 152-162.

[7] W. Dai and L. Fan, "Discussion about the Pros and Cons and Recommendations for Multimedia Teaching in Local Vocational Schools", Physics Procedia, vol. 33, (2012), pp. 1144-1148.

[8] R. Khansa, "Teachers' Perceptions toward School Counselors in Selected Private Schools in Lebanon", Procedia - Social and Behavioral Sciences, vol. 185, (2015), pp. 381-387. 